\title{
EBLIDA's Action in Europe
}

\author{
by BRITT MARIE HÄGGSTRÖM
}

\section{INTRODUCTION}

EBLIDA is the European Bureau of Library, Information and Documentation Associations. EBLIDA is an independent umbrella association of national library, information, documentation and archive associations and institutions in Europe. EBLIDA was founded in 1992. The initiative to start a new organisation for libraries in Europe came from Germany, UK, Denmark and The Netherlands. Members of EBLIDA are national associations for librarians and archivists. EBLIDA do also have libraries and archives as institutional members.

\section{OBJECTIVES AND ORGANISATION OF EBLIDA}

The objectives are to serve and promote the interests of the library and information science profession at European level, ranging from the European Commission to the European Parliament, the Committee of the Regions, the Council of Ministers and the Council of Europe; to give the members up-to-date information on all relevant developments in the European Union; to strengthen co-operation between the members.

Values for the EBLIDA members:

- $\quad$ promotion of interests

- $\quad$ active involvement of members in European information policies

- consultation and advice

- information on European developments

Participation in relevant EU projects. like:

ECUP - European Copyright User Platform

CECUP - Central and Eastern European Copyright User Platform

CELIP - Central and Eastern European Licensing Information Platform

TECUP - Test bed implementation of the ECUP framework (business models in the electronic information market) 
PULMAN - PUblic Libraries Mobilising Advanced Networks

CALIMERA - Co-ordinating IST for Europe's local cultural institutions

The EBLIDA newsletter EBLIDA Hot News, the EBLIDA monthly newsletter on European library \& information society issues includes information on European directives, programmes, news and events of interest to the library and cultural heritage community. Update on European Funding Opportunities offers a digest of e.g. calls for proposals, tenders, expressions of interest, written questions by members of the European Parliament and legislative and non-legislative proposals.

EBLIDA welcomes professional associations in Member States of the European Union engaged on a national representative level in pursuing the interests of library and information science services; organisations in Member States of the European Union whose members are in a majority drawn from Member States of the European Union. Admission as associate member is open to similar organisations in European states which are not members of the European Union.

\section{LOBBYING}

EBLIDA is a small organisation but very efficient in lobbying for the sake of libraries and archives. Lobby issues are often seen as activities for rich organisations. This is not quite true. Lobbying can be very efficient in a small, but well organised, organisation. The lobbyist needs to know the subject very well, have and develop a network of useful contactpersons in the Commission and the Parliament.

EBLIDA is involved in different policy issues at different lobbying levels as appropriate. Some require quick and intensive action, whilst others have to be tackled from a perspective circumscribed to the monitoring level. The allocation of EBLIDA lobbying issues to one category or the other depends very much on the current approach by the European Institutions' agendas towards those matters. The EBLIDA Annual Work Programme reflects this classification on a yearly basis.

The broad policy issues in which EBLIDA should act are:

- Intellectual property rights [including WIPO issues]

- Information Society issues

- Professional Education

- Culture 
- International Trade matters [e.g. GATS \& TRIPS]

EBLIDA lobbies to defend and promote the interests of the library, archive and information sector and professionals in Europe, following mainly the policy agenda of the European Commission. The lobbying efforts of EBLIDA operate in two directions:

- Influencing the European and International institutions and organisations.

- $\quad$ Providing support to national member organisations.

Influencing European Institutions and officials, and achieving positive results, is not a single-direction task. There are many possibilities for action, but often a combined effort is required to achieve a successful outcome. EBLIDA acts mainly through its Secretariat, headed by the Director, who is responsible for the management of relations with the European Institutions and international organisations.

As regards its members, it is the EBLIDA commitment to encourage, inspire and support their national lobbying actions, providing the necessary alert and background information when action is required towards a certain policy issue. EBLIDA works through position papers. A position paper is a statement agreed by the executive board. The position paper is sent out to all members of the European Parliament and the Commission. All members are supposed to translate and use the EBLIDA position paper in their national lobbying activities. It is crucial for EBLIDA's lobbying activities that statements and Position Papers in relation to a certain subject, are carefully prepared, issued and disseminated, in order to maintain and develop institutional and political relations. Examples of the position papers can be found on the EBLIDA website. The list given in the appendix provides an overview of the scope of EBLIDA'S actions in recent years.

The EBLIDA working groups are a useful and consistent means of lobbying, adding value to the Secretariat actions towards certain policy issues e.g. EBLIDA's Copyright Expert Group (CEG) and the World Trade Organization Working Group (WTO). These ad hoc groups have proved to be crucial, not only for providing expertise and support to the Secretariat in complex matters, but also for the active involvement of the members in raising national awareness and dissemination of the EBLIDA actions. Members of the working groups are appointed from EBLIDA members' organizations. Their functioning is efficient and well structured and members of the working groups are in permanent contact with the Director of EBLIDA, mainly via e-mail. The working groups also meet twice a year for in-depth discussions of the issues concerned. The new EBLIDA working group on Professional Qualifications (PQ) will be constituted in 2004, as approved by the Executive Committee and the Council. 
As a complement to the lobbying mechanisms, EBLIDA participates in transnational European Commission funded projects whose main goals are in line with EBLIDA's objectives and mission. This allows EBLIDA to further expand its network.

EBLIDA has worked many years and the organisation is best known for the work concerning the copyright directive. It is important that libraries and archives play an active role in all areas of the information society. The copyright issues have an important impact on all libraries. It's a very complicated area and we all need somebody to give voice for our opinion and to initiate discussions on copyright matters to libraries and to the Commission. EBLIDA tries to play this role in Europe.

\section{WEB SITES REFERRED TO IN THE TEXT}

CALIMERA - Co-ordinating IST for Europe's local cultural institutions. http://www.calimera.org/default.aspx

CECUP - Central and Eastern European Copyright User Platform. http://www.eblida.org/cecup/

CELIP - Central and Eastern European Licensing Information Platform. http://www.eblida.org/celip/

EBLIDA - European Bureau of Library, Information and Documentation Associations. http://www.eblida.org/

ECUP - European Copyright User Platform. http://www.eblida.org/ecup/

TECUP - Test bed implementation of the ECUP framework. http://gdz.sub.unigoettingen.de/tecup/

PULMAN - PUblic Libraries Mobilising Advanced Networks. http://www.pulmanweb.org/

\section{APPENDIX: EXAMPLES OF POSITION PAPERS}

\section{European Copyright and Intellectual Property Rights}

Collecting societies Response; EBLIDA Response to the European Commission consultation on the Communication from the European Commission to the Council, the European Parliament and the European Economic and Social Committee on the management (COM (2004)261 final, Brussels, 16 April 2004). 
EBLIDA Statement on the infringement procedures over Public Lending Right, March 2004.

EBLIDA Position on European Parliament Committee on Legal Affairs and the Internal Market Report (First reading) on the Proposal for a Directive of the European Parliament and of the Council on measures and procedures to ensure the enforcement of intellectual property rights (A5-0468/2003, 5 December 2003), also available in DOC Format, December 2003.

EBLIDA Position on the Proposal for a Directive of the European Parliament and of the Council on measures and procedures to ensure the enforcement of Intellectual Property Rights (also available in DOC Format), August 2003.

Comments on the Follow-up to the Green Paper on Copyright and Related Rights in the Information Society (20 November 1996), 25 April 1997.

All are translated to different European languages.

\section{GATS, WTO General Agreement on Trade in Services}

EBLIDA Response to the EC consultation on WTO members' requests to the EC and its member states for improved market access to services, January 2003 EBLIDA Statement on the WTO GATS negotiations, Libraries and trade in services, November 2002 (also available in PDF Format).

\section{Information Society}

EBLIDA Response concerning the future of the information networks of Info Points Europe, November 2003

EBLIDA Declaration on the European Parliament Resolution on The role of libraries in modern society, 3 November 1998

EBLIDA Contribution on Libraries and the Information Society, June 1998

\section{Public Sector Information}

EBLIDA Response to the Green Paper 'Public Sector Information: a key resource for Europe' [COM (1998)555EC 1998], also available in DOC Format, 10 June 1999

\section{Culture}

EBLIDA Statement to the European Commission Memorandum on Lifelong Learning, June 2001 


\section{BRITT MARIE HÄGGSTRÖM}

EBLIDA Contribution to the consideration on the subject of a single European Union Programme for Culture, 27 November 1997

EBLIDA Recommendations on Libraries as information partners in Europe: eliminating frontiers, November 1995 